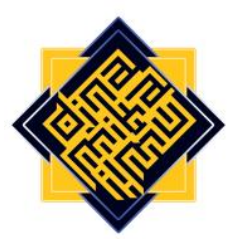

\title{
Islamic Spiritual Education in the Tradition of Bapalas Bidan In Banjar Tribe, Indonesia
}

\author{
Ahmad Harisuddin \\ Student of the Islamic Education Doctoral Program, UIN Antasari Banjarmasin, Indonesia \\ e-mail: ahmadharisuddin79@gmail.com
}

\begin{abstract}
The multidimensional crisis that encourages the importance of developing a spiritual education model based on ethnopedagogy is the background of this research. The goal is to find the content of Islamic spiritual education in the tradition of bapalas bidan or batapung tawar, which is a rite of passage for the early life stage of the Banjar tribe. This qualitative research used an ethnometodological design in the Banjar Hulu and Banjar Batang Banyu areas represented by Hulu Sungai Selatan and Tapin Districts, with criteria-based subjects, combined quouta types and comparisons between cases. Data were collected by engaging observation and indepth interviews; analyzed by modification of Spradley's cyclic model, which checked its validity according to the degree of trust, transferability, dependence, and certainty. This study found that the tradition of bapalas bidan can be categorized as a form of spiritual education based on the religion of Islam. At a philosophical level, this tradition symbolizes the trilogical relationship: God-man-nature through a process of meaning in the form of tabarruk and tafâ'ul towards the ideal Banjar personality, namely baiman, bauntung, and batuah. Psychologically, this tradition is an expression of gratitude and moral responsibility to prepare an initial environment that is conducive to human spiritual development. As for theoretical education, this tradition describes the transfer of knowledge and spiritual transfer of values which is supported by the findings of neuroscience so that it can be reconstructed in ethnopedagogy-based learning models.
\end{abstract}

Keywords: Banjar tribe, bapalas bidan, Islamic spiritual education 


\section{Ahmad Harisuddin}

\section{A. Introduction}

The multidimensional crisis that has hit humans since the end of the 2oth century has aroused a growing interest in spirituality. Brussat and Brussat term it spiritual literacy (Brussat \& Brussat, 1998; Holmberg et al., 2021). This development is very visible in psychology, especially in psychotherapy, and recently has also penetrated the world of education, giving rise to the term spiritual education (Carr, 2003; Ryandi, 2016).

Spiritual education has long been known in the traditions of various ethnic cultures in the world (Rozi, 2018). In fact, the study of Gone et al. shows that spiritual traditions do not just disappear amidst the hegemony of globalization (Gone et al., 2017). Anthropologically, this geneology of spiritual education can be traced from the idea of a soul or spirit in ancient humans that emerged through their experiences in dreams, namely the feeling of actually visiting a certain place, as if something inside them was able to leave the body and roam everywhere, as well as being able to acquire knowledge that could not be obtained while on guard (Lang, 1898). Spirituality, thus, is one cultural entity that cannot be avoided (Tillich, 1964). From here, various forms of spiritual beliefs and traditions emerge, including of course, those with spiritual education.

Spiritual education is always related to the human soul or spirit because of the many species on this earth; only humans have a spirit with all the functions of their personality (Barnes, 1983). Spiritual education, thus, is an educational activity that is focused on the dimensions of the human spirit, namely developing spiritual potential such as religious motives, holding on to piety, love for truth, goodness, and justice, and hatred for evil, badness, and injustice (Najâtiy, 2001).

In certain ethnic-cultural circles, including in Indonesia, spiritual education has been implemented for human children from a very early age, even from prenatal. Various beliefs and cultural traditions also develop in the context of spiritual pedagogy, such as totems, taboos, rites, art, proverbs, and other forms that are framed in a tradition with educational content.

The Banjar tribe, as an integral part of the Indonesian nation which is centered in the Province of South Kalimantan, is parts of Central Kalimantan, and parts of East Kalimantan, has long been known to have various traditions that contain spiritual education (Noor, 2013). One of them is the bapalas bidan, which is the tradition of blessing newborns and their mothers (Daud, 1997). Indeed, the bapalas bidan are not only known in the Banjar tribe, but also in the traditions of the Dayak tribes in the Meratus Mountains of South Kalimantan and also the Bakumpai Tribe who inhabit along the Barito River both in South Kalimantan and Central Kalimantan (Norsam, 2018). It's just that, the bapalas bidan in the Banjar tribe as the owner of this tradition has been recorded at the Ministry of Education and Culture as an Intangible Cultural Heritage in 2015.

The tradition of bapalas bidan can be found throughout South Kalimantan as the basis of Banjar culture, which consists of the Banjar Kuala, Banjar Batang Banyu, and Banjar Hulu areas. However, based on preliminary studies, the tradition of bapalas bidan in the Banjar Kuala area does not include bapalas as the core of the ceremony, replaced by batapung tawar, although some people still call them bapalas bidan. This tradition still shows traces of 
a local culture that are relatively more genuine in the Banjar Hulu and Banjar Batang Banyu communities based on their genealogy which can be traced to the Maanyan tribe as residents of the southern and southeastern parts of the island of Kalimantan, which previously existed (Subiyakto, 2006).

The tradition of bapalas bidan is interesting to study in the landscape of Islamic spiritual education, at least for two reasons: First, there is a continuity of dynamic traditions from local cultural roots to Islamic culture (Hartatik, 2017). In this context, the presence of Islam maintains the substance and form of the bapalas bidan tradition, but changes its theological orientation and practically makes it a medium for spiritual education. Second, the tradition of bapalas bidan allows it to be reconstructed as a new perspective in the development of spiritual education models based on ethnopedagogy, or vice versa, spiritual ethnopedagogy, especially in the family or community environment.

Based on searches of various studies, research on ethnic traditions with spiritual nuances have been conducted, among others, in the culture of Aboriginal people (Rigsby, 1999), in the context of taboo spirituality in South America (Ver Beek, 2000), mestizo spirituality in Mexican health culture (Cervantes, 2010), in Banjar culture (Budhi, 2015; Buseri, 2011; Noor, 2013), in Hindu-Balinese culture (Budiasa, 2015), in Bugis society (Mardia, 2016), in Kazakhstan culture (Tuyakbaeva, 2016), in the American Indian community (Gone et al., 2017), in the spiritual tourism tradition of Iran (Zareei \& Namjoo, 2018), Indian tribal culture (Rowkith \& Bhagwan, 2020), and Wage Keramat in the Javanese spiritual communal tradition (Hanifah, 2020). As for research on spiritual education in various traditions, among others, is found in pencak silat (Nahrawi \& Hartono, 2017), temu manten manten (Subandi, 2018), pilgrimage traditions (Mahzumi \& Fuad, 2019), and mandi kembang (Nuha \& Nisak, 2020). There is also research related to the combinative effect of local wisdom and spiritual intelligence on student behavior (Setiadi, 2019), and research on family support for children's spirituality education (Herawati et al., 2019).

Meanwhile, there are several studies that have explored the tradition of bapalas bidan. Alfani Daud reports various Banjar cultures, one of which is about the bapalas bidan and finds a substantive meaning in the form of a blessing by a midwife to a baby and its mother. The purpose of this ceremony is as remuneration for the midwife and atonement for the bloodshed during childbirth (Daud, 1997). Wajidi researched the acculturation of Islam and Banjar culture in Banua Halat, Tapin Regency, one of which highlighted the bapalas bidan's ceremony, one of which was a childbathing ceremony as a continuation of the pre-Islamic tradition, from local religious elements to Hinduism, which was later adapted to Islamic teachings (Wajidi, 2011). Shapiah researched the values of Islamic education in the tradition of birth in the Banjar tradition, such as mandi badudus, birth, Batasmiyah/aqiqah, batindik, baayun, and basunat (Shapiah, 2015). Emawati examines the historical dynamics of the baayun anak's ceremony in Sampit, Central Kalimantan, where one of the processions is the bapalas bidan (Emawati, 2016). Also found, Rosyida researched the relationship between religion and local wisdom on social change in the Banjar community, where the bapalas bidan are among the traditions that have local wisdom (Rosyida, 2016). There is also Tardi Edung's research on balian palas bidan in the Dayak community (Edung, 2019); and Resviya's 


\section{Ahmad Harisuddin}

research on bapalas bidan in the Bakumpai Tribe (Resviya, 2020). From all existing research, the content of spiritual education in the tradition of bapalas bidan has not been fully and systematically explored.

Based on the above background, the problem that will be examined in this research is how is the content of Islamic spiritual education in the tradition of bapalas bidan in the Banjar Tribe, Indonesia? In accordance with ethnographic objectives, this study aims to obtain an overview of the content of spiritual education in the tradition of bapalas bidan in the Banjar Tribe as research subjects.

Theoretically, this study seeks to strengthen new perspectives in ethnopedagogy studies in Indonesia (Suratno, 2010). In practical terms, the results of this study can be used as material for curriculum development with an ethnopedagogical spiritual perspective both in universities and in schools and madrasas with a focus on local content.

\section{B. Theory of Spiritual Education}

Spiritual education is education based on the development of the spiritual potential of students. This definition is in accordance with the view of the humanistic-transpersonal school of psychology that humans have a number of potentials in themselves, and one of them is spiritual potential (Kontrimiene, 2019). In fact, this is the main human potential, because as Rudolf Steiner emphasized, the essential human essence is that he comes from the spiritual world (Steiner, 2004).

The term of spirituality used here refers to the narrow meaning of Tisdell's spirituality, namely the forms of consciousness that respect the role of the Life Force in everything. This definition is explained through seven characteristics (Tisdell, 2003), which in the context of this research is simplified by modification in the form of the following four features:

1. Spirituality is an appreciation of belief in the Absolute and Whole Substance, whether a belief is in the form of religion or not.

2. Spirituality is self-awareness, although the spiritual experiences that occur in the formation of knowledge are sometimes outside of consciousness or take place subconsciously.

3. Spirituality aims to find the authentic meaning in life.

4. Spirituality includes an atmosphere so that it can be developed in the form of an educational environment.

In the Islamic tradition, the four characteristics of spirituality have similarization, or at least parallelization (Mujib, 2008), with the concept of ihsân, namely appreciation in faith and Islam; khusyû ', which is full self-presence; niyah, namely giving meaning in every activity; barakah, namely goodness that spreads, is facilitated, and continues to increase (Ibn Fâris, 1979; Leaman \& Ali, 2008); and tafâ'ul, namely optimistic thinking in the form of positive beliefs and hopes for something that is heard, seen, said, or done (Amin, 2019; Mohd et al., 2011; Usman, 2015).

Meanwhile, in humanistic psychology, it is humans who construct meaning based on a number of potentials that exist within themselves in the form of beliefs, expectations, and 
sensitivity (Rogers, 1995). This is in accordance with the phenomenological philosophy that all kinds of objects and events will only have the meaning as long as humans give meaning to them (Cox, 2006). Therefore, it is natural that there are different meanings to an object, tradition, or event among societies that have cultural differences, even though they are still in one ethnic bond.

The meaning of society turns out to be able to form collective beliefs which neuroscientifically have an influence on the reality in that society (Newberg \& Waldman, 2013). In relation to generally accepted spiritual values, Tony Buzan identifies 24 values, namely truth, honesty, courage, simplicity, compassion, cooperation, freedom, peace, love, understanding, charity, responsibility, tolerance, integrity, trust, purity, unity, gratitude, humour, persistence, patience, justice, equality, and harmony (Buzan, 2002).

Spiritual education has been developed through three different approaches (Carr, 2003). First, spiritual education is based on religion (traditionalist). As an example, the mainstream religious groups in Indonesia seem to take over spirituality (Muttaqin, 2012). Empirical studies indicate that the sacred has powerful implications for human behavior (Pargament, 2007). Second, cultural-based spiritual education (modernist), based on constructivism that seeks to maintain objectivity and universality of forms of spirituality development from various culturally conditioned religious perspectives, so that they are not biased towards certain religions. This idea refers to the views of cognitive developmentalists such as Piaget and Kohlberg. Third, attitude-based spiritual education (postmodernist), is applied to the attitude domain in a cross-curricular manner with a number of reductions, including avoiding discussion of the occult (Carr, 2003).

\section{Research Methodology}

This research is a qualitative study with an ethnographic-ethnometodological design, which describes beliefs, culture, and traditions as the community itself believe and is aware of it (Muhadjir, 2002). Ethnography itself is defined as an investigation of behavior patterns, language, and actions of a cultural group in a natural environment over a long period of time (Creswell, 2014).

The object of this research is the content of Islamic spiritual education in the tradition of bapalas bidan in the Banjar Tribe. There are nine key questions that serve as a guide for extracting data from informants, which are as follows: What does the bapalas bidan mean? Why should bapalas bidan be implemented? When should the bapalas bidan be implemented? Who is involved in the bapalas bidan's ceremony? What materials are needed in the bapalas bidan's ceremony? Why should the materials be provided? How is the bapalas bidan's ceremony? What is the meaning of the bapalas bidan's ceremony? What is the position of the tradition of bapalas bidan in the context of Islamic education in the family and community?

Tanah Banjar, South Kalimantan, Indonesia, is the research setting chosen because it is the basis of Banjar culture. Then, because from the perspective of its origins, the more genuine Banjar culture is in the Banjar Hulu and Banjar Batang Banyu areas, the research locations were determined in two districts, namely Hulu Sungai Selatan and Tapin. The 


\section{Ahmad Harisuddin}

reason is that these two regions have gathered two Banjar Sub-Tribe, namely Banjar Hulu and Banjar Batang Banyu. These locations are Jambu Hulu Village, Taniran Kubah Village, Gambah Dalam Village, Panggandingan Village, and Hamayung Village for Hulu Sungai Selatan District; Tatakan Village, Paul Village, Parigi Village, Kepayang Village, and Margasari Hulu Village for Tapin District. In terms of sub-tribes, the villages of Jambu Hulu, Taniran Kubah, Tatakan, Paul, Kepayang, and Parigi represent the Banjar Hulu Sub-Tribe, while Panggandingan, Hamayung, and Margasari Hulu Villages representing the Banjar Batang Banyu Sub-Tribe. These villages were selected as an extreme, distinctive, and exemplary sample in order to obtain conclusions on cases that have high comparability according to the characteristics of ethnomethodological research (Muhadjir, 2002).

This research was conducted in three stages. The first phase is from March 2015 to May 2015; the second phase from May to June 2018; and the third phase from April to November 2020. The length of time in the research was intended to ensure that the data collected and analyzed were truly reliable and consistent.

Research subjects were selected using creation-based selection with a combination of two types, namely the quota type and the comparison type between cases (Muhadjir, 2002). The first level selection of key informant quota is the Banjar Hulu community and the Banjar Batang Banyu community. From there, the second level of key informants were taken, namely the main actors of the bapalas bidan, plus other informants from the participant element. Then, at the third level, key informants were taken from the main actors, namely midwives, parents of babies, and tutuha (eldery) from the community, totaling 13 people; then coded in sequence, I-01 to I-13. The selection based on comparisons between cases was carried out in the extreme, typical and exemplary cases.

Table 1: List of Key Informant

\begin{tabular}{|l|l|l|l|}
\hline Code & \multicolumn{1}{|c|}{ Element } & \multicolumn{1}{c|}{ Address/Village } & \multicolumn{1}{c|}{ Sub Tribe } \\
\hline I-01 & Village midwife & Parigi & Banjar Hulu \\
\hline I-02 & Village midwife & Kepayang & Banjar Hulu \\
\hline I-03 & Village midwife & Hamayung & Banjar Batang Banyu \\
\hline I-04 & Village midwife & Taniran Kubah & Banjar Hulu \\
\hline I-05 & Village midwife & Tatakan & Banjar Hulu \\
\hline I-06 & Village midwife & Jambu Hulu & Banjar Hulu \\
\hline I-07 & Elder & Panggandingan & Banjar Batang Banyu \\
\hline I-08 & Elder & Taniran & Banjar Hulu \\
\hline I-09 & Elder & Margasari Hulu & Banjar Batang Banyu \\
\hline I-10 & Elder & Gambah Dalam & Banjar Hulu \\
\hline I-11 & Village midwife & Paul & Banjar Hulu \\
\hline I-12 & Elder & Paul & Banjar Hulu \\
\hline I-13 & Parents & Paul & Banjar Hulu \\
\hline
\end{tabular}


Data collection was carried out by engaging observation techniques and in-depth interviews, who are technically assisted by a research assistant. Observations of involvement bapalas bidan were carried out in 3 extreme cases, while in-depth interviews were carried out in extreme cases, typical cases, and exemplary cases in order to explore the values of spiritual education.

The data analysis of this study used the Spradley cyclical model with a number of modifications. Data collection and analysis are carried out in an integrated manner in seven processes, namely descriptive observation, domain analysis, focused observation, taxonomic analysis, selected observations, component analysis, and theme analysis (Moleong, 2005). The data validity checking technique uses four criteria, namely credibility, transferability, dependability, and confirmability (Moleong, 2005).

\section{Findings}

\section{Meaning of Bapalas Bidan}

The word palas comes from the ancient language of the people of Kalimantan Island, which is still mostly used by the Dayak people, such as the Kendawangan Tribe in West Kalimantan, the Ngaju Tribe in Central Kalimantan, and various indigenous communities in the Meratus mountains with the meaning "smearing something with blood". In the Halong Dayak culture, the term palas means purification by smearing animal blood (Hartatik, 2017). As for the Dayak Meratus people in the upper reaches of the Tapin river, they type palas with a blood ransom so that after being redeemed, there will be no more blood spilled among the palas subject concerned (Wajidi, 2011).

The composer of the Banjar Language Dictionary noted the use of the term palas initially referred to the process of salvation with animal blood (Hapip, 1994). However, there are exceptions to the Dayak Deah communities in Liyu and Gunung Riyut Villages, Halong, because they lazy their babies with a mixture of eggs and coconut oil, not with blood (Hartatik, 2017). This seems to be correlated with the Banjar Kuala community who still uses the name of the bapalas bidan's ceremony, but there is no longer a procession of bapalas with the blood but instead replaced by a procession of tapung tawar using likat buburih oil (Shapiah, 2015). Even so, palas which means smeared animal blood, can still be found in Paul Village. According to an informant: "Darah babalungan hayam nang dikasaiakan ka dahi kakanak habang itu gasan mangganti darah nang habis wayah baranak" (I-11). This means that the chicken's comb blood smeared on the baby's forehead as a substitute for the blood that was spilled when the mother gave birth. From the various meanings of the word palas, it can be understood that palas is a purification ceremony through blood ransom which aims to maintain one's safety from spilling blood again in the future.

Considering that the term palas has a rather negative connotation in the perspective of Islamic teachings, which stipulates the impurity of blood, some of the Banjar tribes no longer use the term in baby blessing ceremonies, but have replaced it with the term tapung tawar which was adopted from the culture of Malay origin. Some people pronounce it batampungawar (I-10). According to an informant, the word of tapung tawar comes from tapung baras (rice flour), which is powdered with freshwater (I-08). However, according to

Dinamika Ilmu, Volume 21(1), 2021 


\section{Ahmad Harisuddin}

other informants, formerly, the name of tapung tawar came from liquid flour mixed with bidder leaves, but over time it was replaced by sticky pulp oil (I-07). This is the main reason why there are two different names in the Banjar Hulu community for the same ceremony, namely bapalas bidan and batapung tawar.

According to the informants, the bapalas bidan is a ceremony for the delivery of a baby by a midwife to its parents. In This case, the midwife said: "Kusarahakan anak ngini lawan ikam. Jagalah anak ini baik-baik." The mother replied: "Kuterima anakku." The informant said: "Limbah ngintu jangan lagi seorang bidan tadi, jangan lagi mangibiti." (I-03). This means that after the child surrender procession, the midwife may no longer touch the baby. Meanwhile, an informant stated: "Batampung tawar adalah acara panyarahan bayi dari bidan ka ibunya. Bila kada batampung tawar maka anak itu masih anak bidan" (I-10). That is, the batapung tawar is an event for the delivery of the baby from the midwife to the mother. If the batapung tawar is not implemented, the baby is still a midwife's child. The same thing was said by informant in Taniran (I-08).

Basically, batapung tawar in the postnatal context is not different in principle from the bapalas bidan. Especially in the ceremony, which is named bapalas bidan, there is also a batapung tawar procession. The essence of both ceremonies is affixing an object with certain liquid objects with the same purpose, namely wishing for safety and luck. The difference is in the material and the ceremonial procession. If the bapalas bidan has a ceremonial core in the form of smearing animal blood to the part of the baby's body which is carried out by the midwife, then batapung tawar is more to the core of the procession in the form of splashing liquid other than blood to the baby's body (I-02). The essence of the procession of tapung tawar can be found in the nature of Malay culture with variations around the main ingredients and the sprinkler tools. However, once again in terms of postbirth ceremonies, the Banjar people tend to equate the two terms (Hapip, 1994). In some villages, the terms of bapalas bidan and batapung tawar are even used synonymously and interchangeably (I-02).

\section{Reasons for the Tradition}

Based on interviews with many informants, there are five arguments behind the bapalas bidan ceremony among the Banjar tribe. These five arguments can also be confirmed by the results of previous research.

First, in the ancestral belief of the Banjar tribe, a baby when born is a child of a midwife. This belief is still found in Hamayung. The logical reason is that the midwife takes care of all the affairs of the baby's life, starting from the womb, welcoming the birth, and daily postnatal care until the release of the umbilical cord. So, in order to return the baby to its parents, a bapalas bidan is performed; and this is relevant to previous research (Daud, 1997; Emawati, 2016; Resviya, 2020). An informant in Hamayung said: "Kamudian piduduk disarahakan kapada bidan, pangganti anak tadi." (I-03). That is, piduduk that the parents give to the midwife is a symbol of the substitute for the child that the midwife has given to her parents. However, this belief is generally not found in people who call the ceremony batapung tawar, except for those who use the two names synonymously $(\mathrm{I}-02 ; \mathrm{I}-10)$. 
Second, since the birth process, the midwife felt pain all over her body, as if some magical force was trapping her. The informant at Tatakan mentioned that when a woman gives birth, she experiences some kind of rejuvenation of certain parts of her body, so that she gives birth to children and expels various diseases in her body. It is during childbirth that these diseases pass into the body of the midwife who assists in childbirth (I-05). This phenomenon also seems to be related to the origin of the village midwife's expertise obtained from the results of ancestors' descent through dreams (Daily, 2018). This lasts until at least the seventh day or when the baby's umbilical cord has been released, and according to the informant, the pain will disappear if the bapalas bidan ceremony is held (I-05).

Third, the baby's body is very liked by spirits, so it will tend to disturb it which results in the baby experiencing kapingitan (sick) if not lazy. This generally applies to certain family titles that are related to the aristocratic ancestors of the Banjar Kingdom. Therefore, if the bapalas bidan are not carried out, the baby can get sick (Daud, 1997). The spirits that can disturb these babies, according to some people, are none other than their own magical twins called tubaniyah, tambuniyah, uriyah, and camariah, if they are not implemented by the bapalas bidan (Jamalie, 2014). With the bapalas bidan, some people believe that the four magical twins will protect the baby from evil spirits (I-02).

Fourth, the bapalas bidan ceremony is a redemption by the baby for the blood flowing in the birth process. According to the belief that is still held by some of the Banjar Tribe, if the blood that was spilled because of the childbirth has been redeemed by the baby, there is a strong hope that in the future there will be no more bloodshed on him, his family and neighbors in the future, either due to fights or accidents (1-05). This fourth reason is also the philosophical meaning of the bapalas ceremony in general, as is still found in the Meratus Dayak community and some Banjar people (Hartatik, 2017).

Fifth, the Banjar tribe is accustomed to expressing gratitude, making peace, or going to fulfill their important needs by inviting family and neighbors, so even though now many traditional beliefs have shifted, the bapalas bidan are still carried out to respect tradition as well as become an arena for mutual apology, especially between the family and the midwife $(\mathrm{I}-12)$.

\section{Actors}

The people involved in the bapalas bidan's ceremony are babies and their parents, people who help with childbirth (midwives), tutuha women or people who are admitted to be more knowledgeable about the bapalas bidan, families, and neighbors with varying amounts depending on their respective economic abilities. Regarding parental involvement, in most areas only the mother is present at the ceremony, but there are certain areas where the father of the baby is involved as it is in charge of handing over the piduduk to the midwife and accepting delivery of the baby from the midwife (I-03).

Bapalas bidan are carried out by village midwives as the main actors according to the beliefs described above (I-02). However, because now there is a rule that births must be handled by a medical midwife, sometimes she is also asked to perform bapalas bidan if the delivery process is not accompanied by a village midwife. Whereas in the case of childbirth 


\section{Ahmad Harisuddin}

carried out in the hospital, the bapalas bidan are still carried out by village midwives or female tutuha in the village where the baby's family lives. In cases like this, there has actually been a significant shift in values because the origin of the baby's belief as a midwife's child is no longer confirmed in the hospital tradition that adheres to standard operational procedures for medical treatment. Therefore, for families who still hold on to this strong belief, they still ask for help from village midwives starting before and after childbirth, so that their emotional connection is not cut off $(\mathrm{I}-13)$.

\section{Ceremonial materials}

The materials needed in the bapalas bidan ceremony are quite varied in various Banjar Tribe villages. However, in principle there are four components of the material, namely: (1) ingredients for bapalas; (2) tapung tawar material; (3) piduduk material; and (4) swing material. For people who have left the Bapalas procession, they only need to provide ingredients for tapung tawar, piduduk, and swing. In fact, sometimes there are families who organize a very simple batapung tawar ceremony with only the ingredients of tapung tawar and only piduduk. Piduduk itself means giving.

The ingredients for bapalas consist of chicken blood, either taken directly from the former of chicken slaughter that is provided for cooking or taken from pieces of babalungan (comb) of chicken. The function of chicken blood is to make up for spilled blood during childbirth. Some people replace this bapalas with mashed turmeric (I-01). Some others put the pieces of chicken's comb into the oil for the tapung tawar (I-02).

The ingredients of tapung tawar consist of coconut oil, perfume, or hair oil, flower water and plain water (I-02; I-05; I-06; I-09). Some people also add spices, and they call it banyu tutungkal (Shapiah, 2015). Indeed, there are variations of ingredients in various villages, but generally there are ingredients from oil, water, and natural fragrance blends such as kaffir lime leaves or with perfume or hair oil. The pamapai (sprinkler) tools are guntung-guntung grass, taratat leaves, pandanus leaves, green coconut leaves formed by simple plaits, or torn banana leaves, also depending on the customs of each area. According to an informant in Kepayang, the taratat leaf sprinkler is used to eliminate all physical and mental illnesses, likat oil functions to remove all bad qualities or traits in babies, while pieces of chicken's comb so that the baby's body is clean and healthy ( I-02).

Piduduk ingredients consist of rice, brown sugar (sometimes replaced with white sugar), coconut shelled with coir. Many people add more raw ingredients for cooking ingredients, such as salt, tamarind, shallots, dry red chilies, and lemongrass, plus threads, needles, and perfume (I-04). This piduduk is full of meaning tafâ'ul. Informants in Kepayang Village mentioned rice tafâ'ul so that the baby would live properly, brown sugar to make a sweet and polite speech, coconut to be a role model, salt so that his speech was followed, spices to please the family. Added more sarong to get used to covering the genitals; powder, comb, and mirror to like to please others; money so cheap sustenance (I-02). The unique materials found in Kepayang and Jambu Hulu villages include roosters. The tafâ'ul so that the baby's life is sufficient (I-02; I-06). 
The swing material consists of two layers of tapih bahalai (sarong without stitching); yellow cloth as the outer layer of the swing cloth, so that the baby is protected from disturbance by spirits and as a repellent (I-02); swing rope; ylang flower, so that the baby gives off a fragrance; puntung (the tip of firewood), so that the baby will be lucky in life; bananas, so that the baby will be cheap in sustenance and a mate (for women) or make it easier to become a big person (for men); and leaf for decoration (I-01).

\section{Ceremonial Procession}

The procession of the bapalas bidan ceremony was also found to be very varied in each village; sometimes even among the Banjar sub-tribes themselves. The following is bapalas bidan in Paul Village, which can be categorized as representing an extreme case, because it still contains a procession of bapalas with chicken blood. The sequence is as follows: (1) The recitation of a congratulatory prayer accompanied by a variety of foods, both cakes and rice with side dishes; (2) the main event in the form of a baayun ritual for the baby with a hanging mirror, comb, and Yasin book on the baby's swing, which is believed to protect him from unseen things that can disturb him; (3) circling the lamp (sitting lamp) on the baby's swing three times in the hope that the baby's future is clear or bright; (4) the maayun piduduk ritual in the form of cooking ingredients, namely 1 liter of rice, brown sugar, and coconut, in which the occupation is intended as alms for midwives; (5) the ritual of rubbing blood from the cutting of the cock's comb on the baby's forehead, which means a substitute for the blood that runs out at birth; (6) the ritual of circling the chicken on the swing three times and continued by feeding the chicken over the baby's head, which if the chicken pegs the bait, it is believed that the baby will parajakian, that is, get easy sustenance; $(7)$ the paikat (rattan) that has been prepared beforehand for the mother and the baby to step over the rattan in a sitting position, is believed to connect the tendons or replace the small veins of the mother which break off after giving birth; (8) the ritual of bapapai or batapung tawar using "minyak likat" mixed with hot water for the mother and her baby, and it could also be that residents who attended the event, accompanied by kur sumangat words to restore their lost enthusiasm due to being shocked by something related with the delivery process, plus the reading of selawat which is also trusted by local residents so that the baby is protected from all diseases, and is smart, luck, and dignity (l-11).

In Kepayang Village, the bapalas bidan are as follows: (1) Swinging sticky rice and boiled eggs before the baby; $(2)$ rocking the baby; $(3)$ circling the rattan around the mother's body three times accompanied by zikr or selawat; (4) reaching the mother and baby's body starting with the head, left shoulder, right shoulder, left hand, right hand, left knee, right knee, left leg, closed right leg; (5) stepping on the money by the baby with the help of a midwife or family party, then continuing to distribute the money by means of being squandered to the audience; (6) submit the position to the midwife; and (7) read the doa selamat (I-02).

The bapalas bidan tradition called batapung tawar in Parigi Village shows an important change in the bapalas ritual which is replaced by rubbing turmeric on the nose, so that the baby will glow and the family will be harmonious. In addition, the swing-making procession 


\section{Ahmad Harisuddin}

is carried out during the ceremony, not before. The process is as follows: (1) The midwife and two village elders sprinkle tapung tawar water on the head of the baby and his mother; (2) applying turmeric that has been crushed over the baby's nose; (3) the midwife carries the baby while leading the reading of Surah Yasin; (4) the midwife swings the baby while singing, which has now been replaced by many verses of selawat; (5) prayer recitation (I-01).

The procession of the bapalas bidan with the name batapung tawar which is a typical case was found in Jambu Hulu Village, in the following order: (1) the recitation of doa selamat; (2) bathe the baby like a normal bath; (3) the ritual of swinging a wrapped rock, so as not to fall, even if the fall is not injured like a stone, while around the swing rice is provided so that it is cheap for sustenance, fish to always remember their parents, because Banjar people always look for fish as side dishes, a cup or a hand washing container in order to choose good and halal food such as someone who is cleaning hands, and candles so that the heart is bright so that it is easy to study; ${ }_{4}$ ) the ritual of tapung tawar in which the mother sits holding the baby while stretching her legs toward the swing, meanwhile the midwife describes the hair of the mother and continues blowing selawat and sprinkling tapung tawar water to the mother, baby and audience; and (5) fighting over coins and cakes by the audience, which means an habit from childhood to like charity (I-06). In several other villages, it was found that after removing the mother's hair, an odd amount of rice was added to get rid of huhuwas, which is any serious obstacle in life or the feeling of always being afraid. However, the peculiarity of the ceremony in Jambu Hulu Village is that what is swung is not the baby, but the stone as tafâ'ul with its sturdiness. The informant said: "Batu bapundut tu supaya jangan panggugur. Amun gugur taguh jua mun gugur kaya batu." (I-06). That is, the wrapped stone is so that the baby will not often fail in life. Even if it fails, he will not give up because he is as powerful as a stone.

The procession of a bapalas bidan with the simple name of batapung tawar was found in Taniran Kubah Village. The ceremony begins in succession: (1) The procession of bapapai (water sprinkling) to the mother, then the baby (the whole body), and finally, the whole invitation with the recitation of selawat; (2) swinging rice and cangkaruk snack; (3) swing the baby; and (4) recitation of doa selamat which is closed by eating together. The swing material is the same as the material used in Parigi Village (I-04; I-o8).

\section{E. Discussion}

\section{Philosophical Meaning: Tabarruk and Tafâ'ul}

In the perspective of Islamic teachings, the bapalas bidan or batapung tawar ceremony, which contains various positive meanings behind the traditional symbols, can be explained in the concepts of tabarruk (achieving blessings) and tafâ'ul (religious optimism). In the context of the bapalas bidan, it is believed that the materials or actors of the ceremony which have a positive character can be transferred to the child who is the target of the ceremony through the tabarruk and tafâ'ul approaches. An informant stated: "Amun kada manggawi bapalas bidan, kada dapat apuah urang bahari." (I-02). That is, if we don't do the bapalas bidan, it means we don't get the blessings of the ancestors. This is in accordance with the hadith, which states that elderly people in a society have blessings (an-Naisâbûriy, 
1990). Also, gathering with many people in terms of goodness has blessings (al-Oazwîniy, 2003). Hearing, seeing, saying, or doing something symbolically in the hope of getting good is tafâ'ul which is also part of the Sunnah of the Prophet Muhammad (al-Bukhâriy, 2009; alQusyairiy, 2011; Mâlik bin Anas, n.d.).

According to the beliefs of spiritual practitioners, since a long time ago, symbols were not identical with spirituality, but spirituality was expressed through symbols (Khan, 1926). Therefore, the positive meanings behind the symbols suggestively in principle can be transferred to a person through the tabarruk and tafâ'ul approaches which are one of the hallmarks of Islamic spiritual education.

The basis for thinking about tabarruk seems to be simpler because all that is needed is an effort to find people, objects, times and places that have been confirmed in the Qur'an and the Sunnah as having blessings. As for carrying out tafâ'ul, it is relatively more difficult because the basis of thinking is husn azh-zhann, which is prejudice against God and fellow humans (Rusydi, 2012). The tabarruk and tafâ'ul approaches are actually attached to the processions in the tradition because both are in the intentions of the actors as expressions of optimistic thoughts and concretized in the form of words and deeds. As an example of tabarruk, an informant at Taniran said that the procession of Bapapai (sprinkling water mixed with oil) was filled with selawat, "supaya sumangat bakumpul bahimpun-himpun." (I04). That is, taking blessings from reciting selawat with the aim of making the spirit of life stronger.

As for the example of tafâ'ul, during the procession of making a swing, the maker intends in her heart while hanging the cananga flower that she is taking advantage of the flower character that always pleases everyone who sees and smells its fragrance, so that then the fun character can be imitated by the baby who will be rocked. Something that occurred to the swing maker, then she said something like: "Mudahan bauntung ai pian disukai orang nang kaya kambang ini." (May you be liked by people like this flower). However, the complete concretitized tafâ'ul approach with this kind of utterance is already rare, and it cannot be confirmed in existing research objects or subjects, because they only manifest intentions in actions.

Philosophically, the bapalas bidan are a naturalist-religious tradition in the form of a process of harmonizing the trilogical relationship: God-man-nature (Chittick, 2007); that have harmonious values (Buzan, 2002). The various natural ingredients that are included in the ceremony almost all have philosophical meanings, such as the ingredients related to the hope of cheap sustenance as the meaning of rice and full of benefits as the meaning of coconut. The Banjar tribe, like other ethnic groups, in this case of course, has a rich treasure related to the meaning of natural objects that have positive characters to be transferred to themselves and the life of the baby to achieve the cultural ideals of the Banjar personality, namely humans who are baiman, bauntung, and batuah (Sarbaini, 2015).

Philosophical meaning is closely tied to the socio-cultural life that becomes the space for it to move, because philosophy in this context is the way of life of a society. As a view of life, of course, these philosophical meanings are consciously produced by the Banjar community based on a number of long experiences from generation to generation. So, 


\section{Ahmad Harisuddin}

according to Tisdell's formula, the spirituality of the bapalas bidan tradition lies in the Banjar people's self-awareness in interpreting this tradition.

It is recognized that the meaning of the tradition of bapalas bidan is experienced from a time and space perspective. This is because changes in collective life views are closely related to the openness of society as an internal factor and the quality of internalization of external elements such as religion, art, and politics. Thus, it is not surprising that there is a varied diversity in the tradition of bapalas bidan from the Banjar Tribe, from those who still maintain the term bapalas bidan as the name of the ceremony by changing the material and orientation according to Islam, to those who prefer the name batapung tawar because it is considered more in accordance with Islamic-Malay custom generally (Usman, 2015).

Ulama, as educators in the midst of society, play an important role in the continuity and change of this tradition. It is strongly suspected that the people of the Banjar Hulu Subtribe on the banks of the Amandit river and its sub-branches generally prefer the name batapung tawar based on the influence of two great scholars as the main educators in the era of re-establishing Islam in Tanah Banjar in the 19th century, namely Tuan Guru Haji Ahmad in Balimau Village and Tuan Guru Haji Muhammad Thaib in Taniran Village (Tim Haeda, 2009). The Banjar Hulu sub-tribe who lives around the coast of the Tapin River is most likely influenced by the role of other educators, namely Tuan Guru Haji Salman alFarisi in Gadung Village who seems to be more preserving local traditional forms, so most of them still use the name bapalas bidan with some Islamization in processions and ceremonial materials, which is then given meaning through the approach of tabarruk and tafâ'ul.

\section{Psycho-spiritual motives}

Psychologically, the tradition of bapalas bidan is an expression of gratitude to God for the birth of a child. Expressions of gratitude vary widely depending on the religion and culture in which people live and learn. For the Banjar community, the bapalas bidan or batapung tawar represents the expression from generation to generation, so that there is no other content related to the ceremony except gladness, happiness, and joy, all of which psychologically contain mere positive thoughts (Rusydi, 2012).

In addition, from the perspective of educational psychology, the midwife bapa bapalas bidan's ceremony is also a collective conscious effort of the family and the surrounding community to condition a good and conducive environment for the growth and development of spiritual potential that is in the person of the baby. This perspective refers to the value of understanding, love, courage, and purity (Buzan, 2002). It also has parallels with the convergence theory that no matter how good human nature is, it will not develop without the support of a good and conducive environment (Khalil, 1996). An informant in Kepayang said: "Bapalas bidan ini bisa jua diadakan lawan bamulud, supaya kakanakan bisa mancintai, manaati, lawan mancuntuh kalakuan Nabi tumatan ayunan." (I-02). This means that the bapalas bidan can also be accompanied by a commemoration of the Prophet's birthday, so that the baby can love, obey, and imitate the Prophet's behavior from the moment he is on the swing; as also stated by the actors in Sampit (Emawati, 2016). 
The Banjar people believe that humans are born in a pure state, without sin, and even have internal potential to grow and develop as beings who carry out a spiritual mission, namely to serve the Creator. Therefore, parents, family, midwives, and neighbors have a moral responsibility even since the pre-natal period to provide a good and conducive environment for the baby's growth and development process so that it does not deviate from its nature (Najâtiy, 2001). It also has reflects the value of charity, responsibility, persistence, and cooperation (Buzan, 2002). An informant said that the purpose of the bapalas bidan is "basalamatan atas lahirnya saurang anak dan pemohonan untuk kasalamatan dan tarhindarnya dari nang kada dihandaki bagi si anak nang dipalasbidani tadi" (I-03). It means the purpose of the bapalas bidan is gratitude for the birth of a child as well as a request for safety for that child.

\section{Pedagogical Perspective}

Seen from the perspective of educational methods and media, the treatment of babies in a series of bapalas bidan processions is a continuation of spiritual education activities with audial media (Smaldino et al., 2019), after previously carrying out a procession of azan and iqamah post-birth. Voice is the most effective educational medium from the time the baby is in the womb to the early stages of life in the natural world. This is because the sense of hearing, which facilitates speech recognition develops earlier than the sense of sight, which facilitates visual recognition (Newberg \& Waldman, 2013); according to the information of the Koran, which prioritizes the word as-sam'a rather than al-abshâr in QS. an_Nahl [16/69]: 78.

There is a strong suspicion from several observations and accounts of the informants, that in the early 19th-century Islamic reform in Tanah Banjar, the bapalas bidan was also heard to the baby and the audience the meanings of all the processions and materials provided at that time, it was not just reading the Koran, selawat, and prayers. There are at least two specific goals of spiritual education contained in the procession of playing symbolic meanings in the bapalas bidan's ceremony. First, for the baby, sounds containing the meanings of futuristic goodness enter the brain as tabarruk and tafâ'ul. This can be confirmed by the results of research in the field of neuroscience (Newberg \& Waldman, 2013; Rakhmat, 2007). Second, for the audience as a form of spiritual education culturally in a deeper and more comprehensive meaning.

Several studies summarized by Newberg and Waldman, show that a baby's brain that grows in a healthy environment, in the midst of people who love, and provide positive stimuli will show increased activity and nervous maturity at the end of the third month (Newberg \& Waldman, 2013). This is where the significance of a ceremony such as a bapalas bidan filled with an atmosphere of joy, feelings of gratitude, prayers, and important hopes that are pinned to the baby so that one day becomes a complete human being in accordance with the guidance of the noble values of the local culture. Normally, none of the parents, family members, neighbors, and even midwives, of course, want misfortune for the baby. On the contrary, they definitely want goodness, luck, and safety from all illness and harm. 


\section{Ahmad Harisuddin}

The meanings found in the tradition of bapalas bidan can be reconstructed into learning models in the world of formal education based on ethnopedagogy, both in schools, madrasahs, and universities. The goal is that students and students can apply a spiritual approach in family and community education. In fact, it does not rule out that the basic values of baiman, bauntung, and batuah contained in the bapalas bidan tradition can be presented in the school education itself as it has long been pioneered in the Waldorf School (Steiner, 2004). Because, strategically in education, the translation of these basic values into spiritual values as characterized by Buzan allows them to be presented and internalized into school life.

\section{F. Conclusion}

Based on the analysis and interpretation of the data above, it can be concluded that the tradition of the bapalas bidan is a rite of passage for the early stages of life in the Banjar community which is very full of Islamic spiritual education content. At a philosophical level, this tradition symbolizes the trilogical relationship: God-man-nature through a process of meaning in the form of tabarruk and tafâ'ul to achieve the Banjar ideal, namely baiman, bauntung, and batuah. As for psychologically, this tradition is an expression of gratitude which has all the dimensions of positive thinking, apart from, of course, as a moral responsibility for families and communities to prepare a conducive initial environment for the spiritual development of a baby. Meanwhile, theoretically, this tradition is a spiritual transfer of knowledge which can be explained based on the findings of neuroscience as well as a transfer of values in the form of education of the noble values of Banjar culture. Then, in order to produce a more tangible impact on education from the tradition of bapalas bidan, this research needs to be further developed into the design of learning models related to local content in schools, madrasahs, and universities.

\section{BIBLIOGRAPHY}

al-Bukhâriy, M. bin I. bin al-Mughîrah. (2009). Shahîh al-Bukhâriy (Cet. ke-6). Dâr al-Kutub 'llmiyyah.

al-Qazwîniy, A. 'Abdillâh M. bin Y. (2003). Sunan Ibn Mâjah. Dar al-Fikr.

al-Qusyairiy, M. bin al-Hajjâj al-. (2011). Shahîh Muslim (Cet. ke-6). Dâr al-Kutub 'llmiyyah.

Amin, M. A. (2019). Peusijuek dalam Perspektif Hukum Islam (Kajian Teori Tafaul). Jurnal Kalam, 7(1), 55-64.

an-Naisâbûriy, M. bin 'Abdullâh A. 'Abdillâh al-Hâkim. (1990). Al-Mustadrak 'alâ ash-

Shahîhain. Dar al-Kutub al-'Ilmiyyah.

Barnes, J. (1983). The Presocratic Philosophers. Routledge.

Brussat, F., \& Brussat, M. A. (1998). Spiritual Literacy: Reading the Sacred in Everyday Life. Simon and Schuster.

Budhi, S. (2015). Kebudayaan Melayu Banjar (Catatan Pengantar Diskusi Musyawarah

Budaya Banjar). 1. 1-5. Retrieved from: 
https://www.researchgate.net/publication/339209375_KEBUDAYAAN_MELAYU_BAN JAR_Catatan_Pengantar_Diskusi_Musyawarah_Budaya_Banjar

Budiasa, I. M. (2015). Kontestasi Ideologi Gerakan Spiritual Sai dalam Budaya Hindu-Bali. Jurnal Penelitian Agama, 1(2), 110-118.

Buseri, K. (2011). Budaya Spiritual Kesultanan Banjar: Historisitas dan Relevansinya di Masa Kini. Al-Banjari, 10(2), 173-184.

Buzan, T. (2002). The Power of Spiritual Intelligence. PerfectBound.

Carr, D. (2003). Three Conceptions of Spirituality for Spiritual Education. In D. Carr \& J. Haldane (Eds.), Spirituality, Philosophy and Education. Routledge.

Cervantes, J. M. (2010). Mestizo Spirituality: Toward an Integrated Approach to Psychotherapy for Latina/os. Psychotherapy: Theory, Research, Practice, Training, 47(4), 527-539. https://psycnet.apa.org/doi/10.1037/aoo22078

Chittick, W. C. (2007). Science of the Cosmos, Science of the Soul: The Pertinence of Islamic Cosmology in the Modern World. Oneworld Publications.

Cox, J. L. (2006). A Guide to the Phenomenology of Religion: Key Figures, Formative Influences and Subsequent Debates. The Continuum International Publishing.

Creswell, J. W. (2014). Research Design; Qualitative, Quantitative, and Mixed Methods Approaches (4th ed.). Sage Publications.

Daily, Arni. (2018). Kekerabatan dan Interaksi Simbolik Bidan Kampung dengan Urang Halus dalam Masyarakat Banjar. Khazanah: Jurnal Studi Islam Dan Humaniora, 16(2), 227-248. https://doi.org/10.18592/khazanah.v16i2.2199

Daud, A. (1997). Islam dan Masyarakat Banjar: Diskripsi dan Analisas Kebudayaan Banjar. Raja Grafindo Persada.

Edung, T. (2019). Fungsi Balian Palas Bidan di Ampah Kabupaten Barito Timur. Widya Katambung: Jurnal Filsafat Agama Hindu, 10(2), 58-77. https://doi.org/10.33363/wk.v3io2.399

Emawati, E. (2016). Ritual Baayun Anak dan Dinamikanya. Jurnal Al Murabbi, 2(2), 158-179. Gone, J., Blumstein, K., Dominic, D., Fox, N., Jacobs, J., Lynn, R. S., Martinez, M., \& Tuomi, A. (2017). Teaching Tradition: Diverse Perspectives on the Pilot Urban American Indian Traditional Spirituality Program. American Journal of Community Psychology, 59(3-4), 382-389. https://doi.org/10.1002/ajcp.12144

Hanifah, M. R. (2020). Wage Keramat Sebagai Tradisi Komunal Spiritual Jawa. JPIPS: Jurnal Pendidikan Ilmu Pengetahuan Sosial, 6(2), 97-105. https://doi.org/10.15548/jpips.v6i2.8025

Hapip, A. D. (1994). Kamus Bahasa Banjar-Indonesia. Almamater Press.

Hartatik, H. (2017). Jejak Budaya Dayak Meratus dalam Perspektif Etnoreligi. Ombak.

Herawati, N., Setyaningsih, \& Herlambang, S. M. (2019). Peran Dukungan Keluarga dan Keharmonisan Perkawinan Orang Tua dalam Pendidikan Spiritual Anak. Wacana, 11(2), 213-221. http://dx.doi.org/10.13057/wacana.v11i2.147

Holmberg, A., Jensen, P., \& Vetere, A. (2021). Spirituality - A Forgotten Dimension? Developing Spiritual Literacy in Family Therapy Practice. Journal of Family Therapy, 43(1), 78-95. https://doi.org/10.1111/1467-6427.12298 


\section{Ahmad Harisuddin}

Ibn Fâris, A. (1979). Mu'jam Maqâyis al-Lughah. Dar al-Fikr.

Jamalie, Z. (2014). Akulturasi dan Kearifan Lokal dalam Tradisi Baayun Maulid pada Masyarakat Banjar. Jurnal El Harakah, 16(2), 234-254.

Khalil, E. L. (1996). Preface. In E. L. Khalil \& K. E. Boulding (Eds.), Evolution, Order, And Complexity. Routledge.

Khan, I. (1926). Complete Works of Pir-O-Murshid Hazrat Inayat Khan Original Texts: Lecture on Sufism 1926 1, December 1925 to March 12, 1926 (Source Edition). Omega Publications.

Kontrimiene, S. (2019). Assessing Spirituality as the Ultimate End: Development and Validation of the Humanistic Spirituality Inventory. Journal of Humanistic Psychology, Online First, 1-24. https://doi.org/10.1177\%2Fo022167819850678

Lang, A. (1898). The Making of Religion. Longmans, Green, and Co.

Leaman, O., \& Ali, K. (2008). Islam: The Key Concepts. Routledge.

Mahzumi, M. A.-Q. A. S., \& Fuad, A. J. (2019). Spiritual Education Through Ziarah Tradition in Syaikh Syamsuddin al-Wasil Tomb Kediri City. El-Harakah: Jurnal Budaya Islam, 21(2), 237-254. http://dx.doi.org/10.1886o/el.v21i2.7030

Mâlik bin Anas. (n.d.). Al-Muwatha'. Dâr lhyâ at-Turâts al-'Arabiy.

Mardia, M. (2016). Kontekstualisasi Nilai-Nilai Pendidikan Spiritual Terhadap Penguatan Budaya Assiddiang Masyarakat Bugis Kampung Guru Pinrang. Edukasia: Jurnal Penelitian Pendidikan Islam, 11(2), 225-252. https://www.researchgate.net/deref/http\%3A\%2F\%2Fdx.doi.org\%2F10.21043\%2Fedu kasia.v11i2.1725

Mohd, H., Taha, A. T., \& Mamat, A. (2011). Pendekatan al-Tafa'ul Menurut Islam serta Contoh Penggunaannya dalam Kitab-Kitab Fiqh. Jurnal Islam Dan Masyarakat Kontemporari, 5(Keluaran Khas), 83-92.

Moleong, L. J. (2005). Metodologi Penelitian Kualitatif (Edisi Revisi, Cet. ke-21). Remaja Rosdakarya.

Muhadjir, N. (2002). Metodologi Penelitian Kualitatif (Edisi IV, Cet. ke-2). Rake Sarasin.

Mujib, A. (2008). Pola Pengembangan Psikologi Islam oleh Mahasiswa Fakultas Psikologi UIN Syarif Hidayatullah Jakarta. Tazkiya: Jorunal of Psychology, 8(1), 428-447.

Muttaqin, A. (2012). Islam and The Changing Meaning of Spiritualitas and Spiritual in Contemporary Indonesia. Al-Jami'ah, 50(1), 23-56. https://doi.org/10.14421/ajis.2012.501.23-56

Nahrawi, I., \& Hartono, D. (2017). Memberdayakan Pendidikan Spiritual Pencak Silat: Solusi Mewujudkan Kedamaian dalam Hidup Bermasyarakat. Jagad 'Alimussirry.

Najâtiy, M. U. (2001). Al-Qur'ân wa 'Ilm an-Nafs (Cet. ke-7). Dâr asy-Syurûq.

Newberg, A. B., \& Waldman, M. R. (2013). Gen Iman dalam Otak: Born to Believe (E. Y. Nukman, Trans.). Mizan.

Noor, I. (2013). Visi Spiritual Masyarakat Banjar. Al-Banjari, 12(2), 149-176.

Norsam, N. (2018). Upacara Bapalas Bidan di Kelurahan Lanjas Kecamatan Teweh Tengah Muara Teweh Ditinjau dalam Perspektif Pendidikan Islam. PPs IAIN Palangkaraya; Unpublished Document. 
Nuha, A. U., \& Nisak, F. F. (2020). Kearifan Lokal: Nilai dalam Mandi Kemabang Leson di Desa Gemblengan Kabupaten Wonosobo. ASNA: Jurnal Kependidikan Islam Dan Keagamaan, 2(1), 1-10.

Pargament, K. I. (2007). The Sacred Character of Community Life. American Journal of Community Psychology, 41(1-2), 22-34. https://doi.org/10.1007/s10464-007-9150-z

Rakhmat, J. (2007). Belajar Cerdas: Belajar Berbasiskan Otak (Cet. ke-7). Mizan Learning Center.

Resviya, R. (2020). Tradisi Bapalas Bidan dan Dinamikanya pada Masyarakat Suku Dayak Bakumpai di Kabupaten Barito Selatan. Jurnal Meretas, 7(1), 94-103.

Rigsby, B. (1999). Aboriginal People, Spirituality and the Traditional Ownership of Land. International Journal of Social Economics, 26(7/8/9), 963-976. https://doi.org/10.1108/03068299910245741

Rogers, C. R. (1995). On Becoming A Person. Houghton Mifflin Company.

Rosyida, D. A. (2016, August 9). Hubungan Agama dan Kearifan Lokal terhadap Perubahan Sosial Masyarakat Banjarmasin. International Conference On Social and Intellectual Transformation of the Contemporary Banjarese, Banjarmasin. http://idr.uinantasari.ac.id/6236/

Rowkith, S., \& Bhagwan, R. (2020). Honoring Tribal Spirituality in India: An Exploratory Study of Their Beliefs, Rituals and Healing Practices. Religions, 11(11), 1-16. https://doi.org/10.3390/rel11110549

Rozi, S. (2018). Melacak Jejak Spiritualitas Manusia dalam Tradisi Islam dan Barat. Tarbiya Islamia: Jurnal Pendidikan Dan Keislaman, 7(2), 149-164. https://doi.org/10.36815/tarbiya.v7i2.222

Rusydi, A. (2012). Husn al-Zhann: Konsep berpikir Positif dalam Perspektif Psikologi Islam dan Manfaatnya bagi Kesehatan Mental. Jurnal Proyeksi, 7(1), 1-31. http://dx.doi.org/10.30659/jp.7.1.1-31

Ryandi, R. (2016). Pengalaman Spiritual Menurut Psikologi Transpersonal (Kajian Kritis Ilmu Tasawuf). Jurnal Kalimah, 14(2), 139-154. http://dx.doi.org/10.21111/klm.v14i2.6o9

Sarbaini, S. (2015). Pendidikan Berbasis Etnopedagogi: Baiman, Bauntung, dan Batuah, Eksplorasi Konsepsi dan Konten Pendidikan Urang Banjar. h. 427-440.

Setiadi, K. (2019). Pengaruh Kearifan Lokal dan Kecerdasan Spiritual terhadap Perilaku Peserta Didik. Jurnal Ilmiah Al-Jauhari, 4(1), 126-151. https://doi.org/doi.org/10.30603/jiaj.v4i1.850

Shapiah, S. (2015). Nilai-Nilai Pendidikan Islam dalam Tradisi Kelahiran pada Adat Banjar. Jurnal Mu'adalah, Vol. III, No. 1, h. 67-83.

Smaldino, S. E., Lowther, D. L., \& Mims, C. (2019). Instructional Technology and Media for Learning (12th ed.). Pearson.

Steiner, R. (2004). The Spiritual Ground of Education (Revised Edition). Anthroposophic Press.

Subandi, A. (2018). Nilai Spiritual Tradisi Temu Manten Adat Jawa dalam Perspektif Masyarakat Buddhis. Jurnal Pendidikan, Sains, Sosial Dan Agama, 4(1), 43-56. 


\section{Ahmad Harisuddin}

Subiyakto, B. (2006). Menelusuri Hubungan Sejarah Antara Suku Maanyan, Banjar, dan Majapahit. Jurnal Kebudayaan Kandil, Edisi 13 Tahun IV, 76-82.

Suratno, T. (2010, November 8). Memaknai Etnopedagogi sebagai Landasan Pendidikan Guru di Universitas Pendidikan Indonesia. The 4 th International Conference on Teacher Education, Bandung. http://file.upi.edu/Direktori/PROCEEDING/UPIUPSI/2010/Book_3/Memaknai_Etnopedagogi_Sebagai_Landasan_Pendidikan_Guru_ Di_Universitas_Pendidikan_Indonesia.PDF

Tillich, P. (1964). Theology of Culture (21st ed.). Oxford University Press.

Tim Haeda. (2009). Islam Banjar: Tentang Akar Kultural dan Revitalisasi Citra Masyarakat Religius. Lekstur.

Tisdell, E. J. (2003). Exploring Spirituality and Culture in Adult and Higher Education. JosseyBass.

Tuyakbaeva, A. Sh. (2016). Traditional Ceremonies and Rituals of Kazakh People as the Reflection of the Spiritual Culture in the Kazakh Cinematograph. International Journal of Environmental \& Science Education, 11(12), 5182-5197.

Usman, A. (2015). Tepung Tawar/Peusijeuk dalam Perspektif Teori Tafa'ul. Jurnal AlMursalah, 1(2), 1-10.

Ver Beek, K. A. (2000). Spirituality: A Development Taboo. Development in Practice, 10(1), 31-43.

http://www.tandfonline.com/action/showCitFormats?doi=10.1080/09614520052484

Wajidi. (2011). Akulturasi Budaya Banjar di Banua Halat. Pustaka Book Publisher.

Zareei, A., \& Namjoo, A. (2018). The Role of Theatre, Rituals and Religious Ceremonies in Improving the Concept of Spiritual Tourism (Case Study: Iran). International Journal of Tourism and Spirituality, 3(1), 122-135. 